\title{
THE IMPACT OF MULTI-LEVEL GOVERNANCE ON ENERGY PERFORMANCE IN THE CURRENT DUTCH HOUSING STOCK
}

$$
\text { by }
$$

Thomas Hoppe and Kris Lulofs

\author{
Reprinted from \\ ENERGY \& \\ ENVIRONMENT \\ VOLUME 19 No. 62008
}




\title{
THE IMPACT OF MULTI-LEVEL GOVERNANCE ON ENERGY PERFORMANCE IN THE CURRENT DUTCH HOUSING STOCK
}

\author{
Thomas Hoppe a and Kris Lulofs ${ }^{b}$ \\ ${ }^{a}$ Ph.D. student, Centre for Clean Technology and Environmental Policy, \\ Faculty of Management and Governance, Twente University, Institutenweg 25, P.O. Box 217, \\ 7500 AE Enschede, The Netherlands,E-mail: t.hoppe@utwente.nl \\ ${ }^{b}$ Assistant Professor, Centre for Clean Technology and Environmental Policy, \\ Faculty of Management and Governance, Twente University, Institutenweg 25, P.O. Box 217 , \\ 7500 AE Enschede, The Netherlands, E-mail: k.r.d.lulofs@utwente.nl
}

\begin{abstract}
The housing sector is responsible for $33 \%$ of total $\mathrm{CO}_{2}$ emissions in the Netherlands. As such, large reductions in $\mathrm{CO}_{2}$ emissions can be gained by increasing the energy performance in the existing housing stock. Yet, several barriers make this difficult. Renovation investments and maintenance costs are high while badly needed norms for energy improvement are absent. Furthermore, market developments and sectoral policies reflect a complex institutional environment in which many actors are interdependent, but also lack an individual sense of urgency regarding energy consumption. In this article, we try to determine how multi-level governance in Dutch housing affects the outcomes of policies aimed at $\mathrm{CO}_{2}$ reduction in the existing housing stock. We examined two housing sectors in the Netherlands: social housing and owner occupancy. We focus on policy implementation problems in the early 2000s. It turns out that the complex multilevel environment severely impedes the realization of ambitious policy goals.
\end{abstract}

Key words: Housing sector, Renovation, Sectoral Policies, Barriers.

\section{INTRODUCTION}

Housing represents a substantive share of energy consumption in the Netherlands, with energy primarily being used for heating, lighting, and appliances. Despite the fact that the energy impact of housing construction became subject of regulation in the context of sustainable development and climate-protection policies, the effect on $\mathrm{CO} 2$ reduction in the total domestic housing stock was relatively small. To a large extent this was due to the annual increase of the number of houses, which has only been slightly more than $1 \%$ [1]. The largest potential for $\mathrm{CO}_{2}$ reduction, therefore, lies in the existing building stock [2]. Regulating renovation and maintenance 
activities of already built and used houses, however, is no policy option. Home renovations are the only time when energy efficiency can be applied as a design criterion. For this reason, improving the energy-efficiency performance of existing houses is a real challenge. These efficiencies are required because the Dutch government is committed to an emission cap of 28 million tons of $\mathrm{CO}_{2}$ equivalent per year by 2010 [3]. However, achieving this ambition is difficult for technical and institutional reasons. Although technology for efficiency improvement in existing houses is widely available, it takes motivation, resources and momentum to implement the efficiency-improving technology. These factors are lacking because of the complex multi-level governance that exists in the Dutch housing system, which is failing to facilitate energy efficiency. The core problem is that decisionmaking and financial resources for energy efficiency improvement are unequally distributed over different governance levels. Among public, semi-public, and private bodies the housing associations bear the costs of investments while all kinds of other actors want to influence the decision-making without investing substantial resources themselves. Only in case of an owner-occupier does the decision maker also bear the costs and achieve the benefit, but here motivation and incentive is the problem.

This paper analyses the impact of the multi-level governance context of Dutch housing on energy-efficiency improvements of existing houses. The research question addressed is: How does the multi-level governance context of Dutch housing affect the outcomes of energy-efficiency policies? The analysis focuses on the instruments for energy-efficiency improvement initiated in the context of Dutch climate policy.

The paper is structured as follows: section two briefly explains the current Dutch housing sector and its energy impact. Section three highlights the multi-level institutional dimensions of the sector, whereas section four emphasizes the problems that impede the sector's main actors to achieve significant energy-performance enhancement. Section five provides the analysis and conclusion on how multi-level institutional factors in the current Dutch housing sector impede and create opportunities for energy efficiency improvement for climate protection.

\section{THE DUTCH HOUSING SECTOR AND ITS ENERGY IMPACT}

The Netherlands has a population of about 16 million inhabitants, who are housed in approximately seven million dwellings. Compared to other OECD nations, the Netherlands has a relatively large share of social housing (rent) in relation to privately owned housing. The type of dwellings is classified by the year of construction, the number of rooms, and ownership. By 2002 the number of houses in the Netherlands had increased by $15.7 \%$ compared to 1990 . The relative share of privately owned houses increased from $45 \%$ in 1990 to $54 \%$ by 2002. Dutch dwellings typically have four or five rooms and the largest number of houses tends to be built for family use. Only $29 \%$ of houses are destined for use by multiple families, such as a block of flats [4].

The year a house was constructed is relevant from the perspective of energy efficiency: the older the house, the less energy efficiency has been a consideration in its construction. For example, the idea of energy efficiency is completely missing from 
houses constructed before 1970. And the share of older houses is substantial. In 2004, $47.3 \%$ of the total housing stock had been built before 1970 . Less than $17 \%$ was erected between 1990 and 2004. Thus, the largest part of the housing stock in the Netherlands is relatively old and has been built in a period when regulations for construction were absent, or if present, not as rigorous as nowadays. Between 2000 and 2004 the average life span of Dutch houses increased from 59 to 63 years [5]. Renovation of old houses is sometimes initiated by law requiring certain quality standards; however, in most cases it is driven by market considerations and individual preferences on quality-related characteristics, such as comfort. Renovation is not directly driven by energy considerations, even though these considerations could be part of the renovation process.

Dutch houses are constructed to withstand the wet and windy Dutch climate. In general Dutch houses are solidly wind-proofed and predominantly heated by natural gas. The whole country is connected to the Dutch natural gas reserves in the northern part of the country, and due to the Dutch gas reserves, natural gas could become the dominant energy source for residential heating [6]. Heating represents about $75 \%$ of total private-energy gas consumption with the remaining uses for hot water (20\%) and cooking $(5 \%)$. The consumption of natural gas per household had continuously decreased from $2,000 \mathrm{~m} 3$ in 1997 to $1,736 \mathrm{~m} 3$ in 2004 , a decline of $13 \%$. In the same period the consumption of electricity increased from $3,155 \mathrm{kWh} /$ year to $3,346 \mathrm{kWh} /$ year in 2002, an increase of $6 \%$ [7]. The decrease of gas consumption can be explained by improved housing construction, better materials and more efficient heating equipment. As in other Western countries, increasing wealth and use of electrical equipment led to a rise in electricity consumption.

\section{THE MULTI-LEVEL INSTITUTIONAL SETTING OF DUTCH HOUSING}

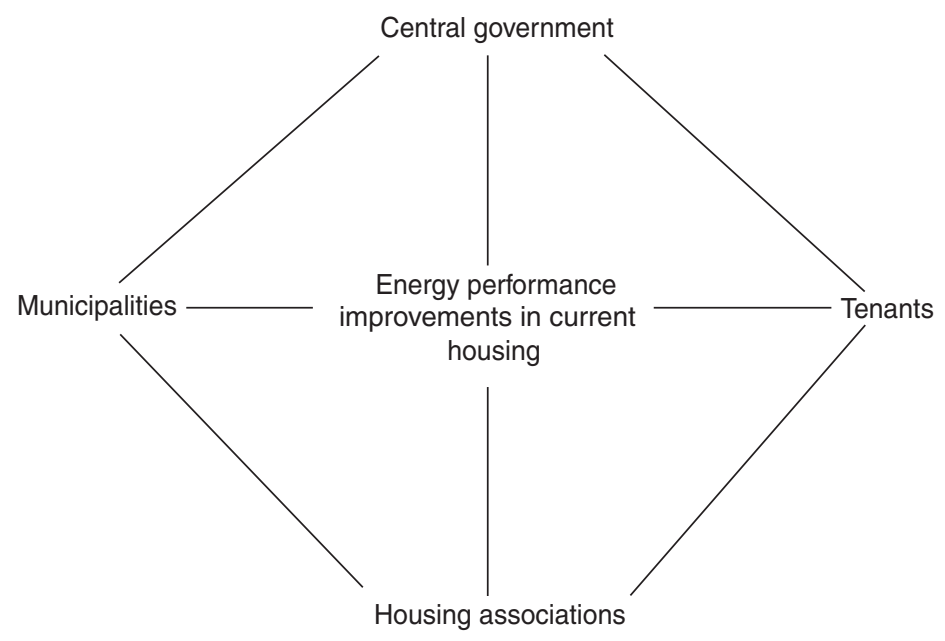

Figure 1: Graphical presentation of the social housing sector. 


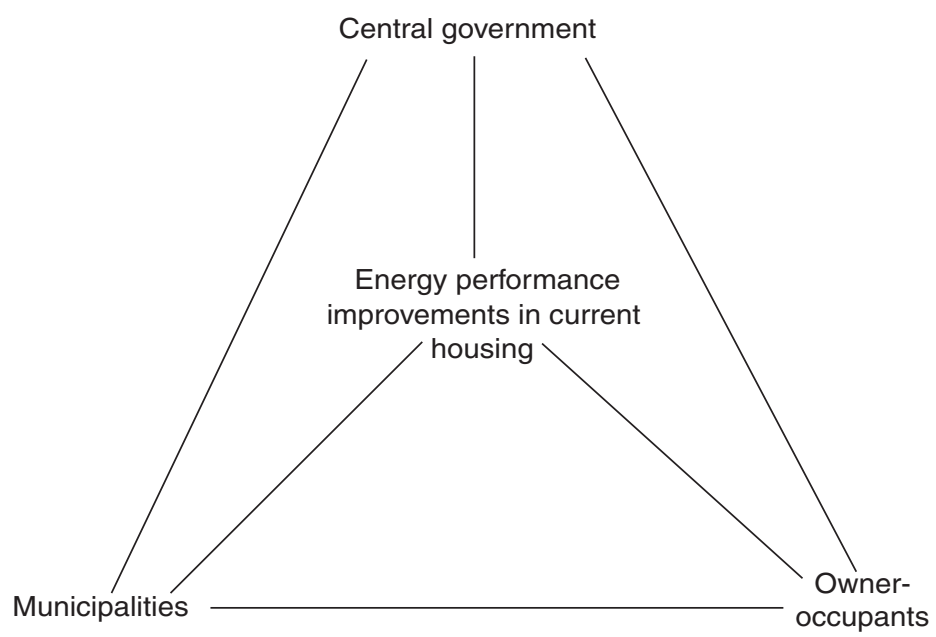

Figure 2: Graphical presentation of the owner-occupied housing sector.

In this section we will explore the housing sectors of social rent and owner occupancy from an institutional perspective. The multi-level institutional organisation of the sector is visualized in figure 1 and figure 2 below.

Figure 1 displays the system in the social housing sector in which multiple levels of government and (primary) actors tend to be in contact with each other over issues of improving energy performance in housing. Each actor, however, is constrained by the institutional framework that defines tasks, responsibilities and interactions. It is important to stress that the social housing sector is divided by ownership and end-use housing. Tenants use the houses for living, while the housing association owns it, completing maintenance and renovation. Although the social-housing sector encompasses approximately 35\% of total housing in the Netherlands, most houses are to be found in the owner-occupied sector, which represents $60 \%$ of the total housing stock. The owner-occupied sector lacks organised interest mediation. Figure 2 presents a graphical presentation of the owner-occupied housing sector.

\subsection{Social Housing Sector}

The Dutch social-housing sector, of which approximately $35 \%$ is owned by associations, has significantly shifted from public to private ownership. From the Second World War up until the 1990s, the social-housing sector was strongly influenced by the public sector and dominated by the national government, who controlled the financing and size of the sector. In the 1990s, neoliberal government sentiments led to liberalization of the housing sector, giving budgetary control to the associations and minimising governmental control. As a result, associations started to build more while selling older stock to tenants and others. Many of the houses that had originally been built with social considerations in mind became privately owned. The central government's role in the sector became one of facilitating at distance instead of managing and controlling the sector. In terms of instruments, this shift was 
characterized by subsidies, emphasis on urban renewal projects and communicative instruments, in particular multilateral agreements in which local actors agreed on longterm neighborhood plans [8].

Housing associations have become social entrepreneurs with a specific public task. Energy and environmental concerns fit well into their public responsibility; however, to date, social goals have driven their involvement in this area rather than concern over climate change. The social concern stimulates associations to improve energy performance of houses so that tenants can feel more comfortable and enjoy lower energy bills. This is particurly relevant for low-income tenants who face the prospect of ever-increasing energy costs.

Housing associations provide their tenants with services by taking measures to reduce the use of fossil fuel by improving insulation or installing high condensation boilers. Many housing associations also instruct tenants in energy efficient behaviour, for example, lowering the in-house temperature, shortening shower times and turning off lights when leaving home. But the social face of the housing associations is changing.

The Dutch social housing sector changed in the 1990s due to liberalization. The number of associations decreased from 1,037 in 1990 to 552 in 2004 (VROM, 1999, 2004). Parallel with up-scaling, the decision-making autonomy of the association increased while the number of social dwellings decreased. Part of this trend was caused by the selling of property to private investors. A shift in financial risk-taking also occurred when many associations started to develop commercial projects in addition to fulfilling their primary mandate to develop and maintain the social housing. Part of this commercialization of activities included demolishing older social house stock because renewing would offer better financial prospects of investments than renovation. Renewing allowed the association to extend the range of tenants, since they were no longer restricted to their traditional tenants with low incomes, but could also pursue middle- and high-income groups who were able to pay higher rents and mortgages. The additional investments in such new houses with improved energy performance, therefore, gave far better returns on investments because the dwelling was no longer limited to the classification "social" with all the accompanying financial and technical restrictions. Since the late 1940s, the Dutch housing sector has faced shortage. In the social sector, this resulted in long waiting times for a house. In general the "market position" of the tenant has been rather weak, particularly with respect to energy performance improvement.

\subsection{Owner-Occupied Sector}

In the privately owned housing sector, owner-occupants both own and use houses. In 2004, this group owned 3.5 million houses nationwide. Owner-occupiers are rarely organized and are therefore a difficult target group to address, for instance through intermediate organisations. The private ownership of houses is expected to grow, which will further complicate co-ordinating action. Private ownership is already highly diversified in characteristics, needs, ambitions, willingness and means to work on the energy efficiency of dwellings. Owner-occupiers tend to organize only on special occasions and then only temporarily [2]. Such occasions, called "natural 
moments", provide "a window of opportunity" when owners are moving, planning to sell a house, renovating, maintaining, or replacing installations.

Owner-occupiers in general are more committed to maintaining the quality of their living environment than tenants. They show more long-term commitment. Nonetheless, compared to organizations and housing associations in general, they tend to lack the awareness, knowledge and expertise on how to apply measures to improve energy performance of houses. Energy performance is also very low on the list of considerations when buying a house. The purchase is dominated by criteria such as location, comfort, the presence of a garden as well as its condition, or the size of the living room. Energy performance-future living costs-are often neglected. High investments (starting from 3,000 for proper insulation and an efficient installation [9]) and the perceived lack of payback in the short- to medium term strongly influence the willingness to invest in energy-saving measures. A municipal or association initiative to collectively renovate houses might inspire owner-occupiers to invest in the improvement of the energy performance of their dwellings. However, this will demand influential 'first movers', organizational effort, and homeowners who are able to make large investments. Moreover, convincing owner-occupiers takes creating awareness, taking away commonly held biases and providing instruments that influence behavioral change. Service contracts with installation agencies could be a means to provide for such incentives and could also sustain efficiency improvements in the longer run.

\subsection{Instruments Aimed at Enhancing Energy Performance of Housing}

In order to influence housing associations and owner-occupiers, several policy instruments have been implemented. The Netherlands has a history of energy and climate policy aimed at the built environment dating back to 1974, the time of the first oil crisis and the 'Limits to growth'-report by the Club of Rome [10]. Since 1974, many instruments aimed at efficiency improvement of dwellings have been initiated, some of them addressing new and some addressing existing houses. Some of the instruments that address the existing stock bear special relevance in the context of this paper. We will first introduce the instruments before analyzing their institutional embeddedness and the problems they present.

The first instrument is Energy Performance Advice (EPA), which is a communicative policy instrument. The EPA is initiated by request of the owner. It provides an expert who offers an energy audit based on a standardised protocol and gives advice on efficiency improvement [11]. Although the instrument is mainly used by owner-occupiers of existing houses, many housing associations have applied as well.

The second instrument is the Energy Premium Regulation (EPR), a subsidy scheme of the national government that supported energy-efficiency improvements in the existing house sector, initially aimed at owner-occupancy, but later applicable to housing associations. The scheme supported investment in sustainable energy, energy saving and energy efficiency. Owners could apply under the scheme when they wanted to implement measures advised under the EPA by a certified advisor. Initially, EPR also covered the full expenses of the EPA. The measure was so popular that it passed the budget ceiling in 2003 and was ended for that reason [12]. 
in the Current Dutch Housing Stock

The third instrument refers to a national programme on sustainable construction packages refers to the national government stimulating local and regional actors to voluntarily apply sustainable construction guidelines to improve the energy performance of housing. The multilateral agreements have been developed in the absence of regulation. To facilitate decision-making, national government provided guidelines on what measures could be taken.

A final instrument worth mentioning in the context of this paper is the urban renewal project. This is actually a programme - a package of instruments - aimed at improving the overall quality of a city area. Improvement of the energy performance is part of the renewal programme. The renovation covers both social and owneroccupied houses and the general approach is to cover as many dwellings as possible at the time. Most projects are initiated when the neighborhood has been labeled as "degraded", meaning low quality houses, social deprivation, unemployment and the like. The renovation starts with developing a guiding vision for the renovation of the neighborhood including the revision of the energy provision. Most energy measures refer to improved construction of the dwellings (insulation, better installations and the like). Urban renewal projects last up to ten years, partly due to changing actors and plans.

\section{IMPLCATIONS OF MULTILEVEL GOVERNANCE FOR ENERGY EFFICIENCY IMPROVEMENT IN THE DUTCH EXISTING HOUSING STOCK}

After having explained the two dominant subsectors of Dutch housing and the instruments for energy performance improvement, this section analyses the multilevel institutional implications of energy performance improvement in Dutch housing.

\subsection{Social Housing Sector}

The most striking institutional problem in the social housing sector relates to the division of owners and users, also known as the problem of 'split incentives'. [13] While the housing association owns the house and covers costs to maintain and renovate, the tenants collect the benefits since their living costs decline due to the renovation. Theoretically the housing association could spread the costs by increasing the monthly rents of the tenant. But in practice, this leads to a number of problems. First most tenants in the social sector have low incomes and cannot afford to pay more rent. Low-income tenants receive a rent subsidy that depends on the fixed rent of the house. If the association charges the tenant for the additional costs of renovation, tenants run the risk of passing the rent subsidy ceiling, which forces them to pay the full rent without assistance. Second, even if the increased rent stays below the subsidy ceiling, tenants hesitate to accept rent increases. It affects their short-term purchasing power, which would already be restricted due to their low income. In fact, this shows that tenants are not open to the argument that they will be better of financially in the longer term. For them, short-term costs outweigh long-term benefits. This lack of support of renovation is quite a relevant aspect of renovation in the Netherlands where at least $70 \%$ of tenants in the neighbourhood need to approve a renovation. It takes a lot of persuasion of the housing association to get this $70 \%$ permission rate. 
Housing associations find it financially far more attractive to move the present tenants out of their renovated houses. In that case, technical and financial restrictions are no longer a barrier in the renovation process and the association can, within certain limits, increase the rent after a renovation to a rate that conforms to the market level. Such renovation conditions allow for far better energy performance improvement measures, especially with innovative installations. Moreover, after renovation, the housing association is allowed to charge the new tenant for the renovation costs, including the cost of energy improvement.

As indicated earlier, the average life span of Dutch houses is 63 years, and renovation often only takes place after more than 30 years. When this particular moment occurs, housing associations want, for reason of economies of scale, to renovate as many dwelling as possible at the same time. Innovation projects, therefore, might cover between 100 and 10,000 dwellings. For this reason, the momentum for renovation is very rare. If renovation is considered, quite some bureaucracy must be overcome before it can actually start. The association and the municipality must sign an agreement with the central government to receive some funding for the project. Apart from the bureaucratic, technical and psychological barriers of renovation projects, energy performance improvement is still no dominant driver. Energy efficiency is a by-product of the overall quality improvement aimed at by renovating houses. The problem also relates to the absence of energy performance standards in renovation regulations in the Netherlands.

Despite these restrictions, the associations were strongly encouraged both by national and local governments to seek energy advice for their housing stock. Many associations did and also subscribed for the EPR subsidy as a follow-up. This contributed to the exhaustion of the EPR subsidy scheme mentioned above. After the termination of the EPR in 2003, the associations lost interest in energy efficiency and energy performance improvement because they did not want to pay for the energy improvement measures by themselves. They considered these investments as unprofitable and for that reason completely lost interest in the energy performance of their stock.

Two other policy instruments, not mentioned yet, could not inspire the sector either: the covenant and the energy performance standard (EPN). The EPN, designed as a guide for the construction of new houses, did not apply to renovation. In renovation, the EPN was assumed to provide a kind of reference for possible measures, but the EPN reference did not function in practice for technical and financial reasons. Despite initially high energy ambitions, costs and technical barriers that affected the ambitions significantly during the renovation process. Many renovation projects, therefore, have been finalised with improvement of the energy performance taking a backseat.

\subsection{Owner-Occupied Sector}

Owner-occupiers would have at least two valid reasons for making vast investments in upgrading their properties. First, in cases where large investment would give them net benefits in the long term (dependent on the payback period). Second, in cases where investments pay off when the house is sold. Both are problematic. Motivation 
for investment in energy performance is often not as well appreciated as comfort, location, size of the living room, and orientation. As a consequence, market-demand favours those housing characteristics over energy performance; market demand for high-quality energy performing houses is simply lacking.

Despite these barriers, the private-housing sector has been targeted by energyefficiency policies. For instance, in early 2000, many Dutch municipalities tried to convince owner-occupiers to have an EPA, with mixed results. On the one hand, while owners could have the EPA initially for free, only those who were already strongly focused on energy performance took advantage of this programme to implement efficiency improvements funded under the EPR. The intended "branding effect" of EPA didn't emerge. The EPA never fully facilitated energy performance as a "unique" selling point in housing transactions due to the absence of a certified energy label. On the other hand, the EPA did inspire owners to seek energy advice and to take measures under the EPR. Consequently, private homeowners contributed to the exhaustion of the EPA and EPR budget. The EPA continued as a service but only on account of owners themselves. The ever increasing costs charged by the EPA advisors also contributed to the exhaustion of the EPA budget.

The change of policy proved to be a serious blow for energy performance improvement in the Dutch private housing sector. An emerging lack of trust in EPA, due to substantive differences in the way the EPA was conducted in the different regions of the country, also discouraged owners. As an alternative, many municipalities tried to persuade owner-occupiers to apply solar collectors and boilers by sending them letters that offered vast discounts on buying the installation systems and hiring installation labor. Nonetheless, response rates of 5\% showed the disinterest among private house owners in energy performance improvement of their dwellings, even when they could benefit from subsidies. However, the analysis shows that policies have not been consistent over the years or have been too strongly of a stopand-go type, which is not very encouraging for house owners. The recently introduced energy label for the existing private house stock is accompanied with similar uncertainties and distrust of the EPA, again because of inconsistencies in the set up and implementation of the instrument. This shows that the Dutch government has not learned from past experiences.

Lately there have been attempts to improve the energy performance of private houses as part of urban renovation projects in the social housing sector. Sometimes part of the house stock nominated for renovation is privately owned: former tenants who become owners after buying their house from the association. It showed that these circumstances make improving energy performance of the privately owned house rather difficult because the in generally low-income owner cannot afford the financial investments needed to join the overall renovation of the neighborhood.

\section{CONCLUSIONS}

What does our analysis of energy performance improvement in the Dutch housing show about the impact of the multilevel governance context in this sector? This final, concluding, section will address this question for social housing and the private sector separately. 


\subsection{Social Housing Sector}

The most important problem with respect to energy performance improvement in this sector is the 'split incentives' where the housing association and tenants have a mutual interest. At the planning stage of renovation projects, the split incentives and instruments of the national government provide tenants bargaining room with the housing association by means of the $70 \%$ approval rule and the rent subsidy cap. Strikingly, ill awareness and a focus on short term costs encourage tenants to bargain for the lowest rent price which often impedes the realization of energy efficient measures in their houses. The multi-level implication is, therefore, that the national government unintentionally intervenes in the bargaining between housing association and tenants, causing energy ambitions to be reduced. These positions might change in the future due to rising energy prices. High energy prices might induce a new awareness by the tenant to approve efficiency measures despite the short-term impact on purchasing power.

A second major multi-level impact on energy performance improvement is the liberalisation of the social housing sector in the 1990s. Liberalisation significantly changed the position and focus of the housing associations as keepers of the public good in housing. Associations developed a stronger commercial focus, which benefited the construction of expensive new houses, neighborhoods and city areas at the expense of renovation and preservation of the existing stock. They also sold many old houses to private investors.

The liberalisation of the social housing sector shaped conditions in which policy instruments aimed at energy performance improvement can hardly be achieved. Associations have been developing a commercial focus in their activities and are no longer willing to make unprofitable investments in their public task. Consequently, the associations required additional subsidies before they were willing to focus on the energy performance of their dwellings. As such, the association's willingness to make unprofitable investments stopped after termination of the subsidy scheme. So the impact of the multilevel institutional context here is twofold. By the introduction of liberalisation, the central government changed the conditions that guided the activities of the associations. This took them away from their public task. The "stop-and-go" nature of energy-efficiency policies also affected the associations' investment behavior in energy performance improvement. The inconsistent subsidy policy from the central government reinforced the negative impact of liberalisation on energy performance improvement by Dutch housing associations.

\subsection{Private Housing Sector}

Energy performance improvement in the private sector is facing two major problems. First owners lack a sense of urgency when it comes to investment in the energy performance of their property. Despite their interest in good energy performance of the house, they prefer investments in quality and luxury improvements. To date, awareness campaigns and even high energy prices have not changed the habits of house owners. Change will take time, but current policies does not allow for this time, given the sudden termination of the EPR, which also let to a serious reduction in the request for EPAs. 
The second major problem for energy improvement in the private housing sector is the economies-of-scale problem. The analysis shows how difficult it is to access such a fragmented and disorganised sector as the private housing sector through policies. Energy performance improvement basically emerges on a case-by-case basis, driven by the individual decisions of private owners. This makes it very difficult to fine tune policies for the private-housing sector. The local level would probably be the best at which to develop and implement policies, but the analysis shows the failure of existing attempts in that direction due to inconsistencies between governance layers and lack of resources at the local level.

Development of a multilevel chain of policies from the central to the local level, with public and private partners, might be considered to overcome these problems. Multi-level cooperation between the central and local government, banks, and housing associations might generate economies of scale since this type of collaboration allows for combining low-rent loans, subsidies and information campaigns. Owner-occupants could be encouraged with an attractive package that would remove difficult deliberation the house owner usually does not to take into account. High energy prices could facilitate the approach since this could reduce payback times for energy improving investments. The analysis also showed how important a consistent and reliable support policy is in this respect. The central government should be more consistent and reliable in providing subsidy budgets. Ideally, the amount of money should allow for a support of at least ten years, allowing house owners to get used to the idea that it makes sense to invest in energy improvement. So, government should be creative, patient but insistent when it comes to energy performance improvement in the private sector.

\section{ACKNOWLEDGEMENTS}

The authors are grateful to Maarten Arentsen for his useful comments on the earlier versions of the paper.

\section{REFERENCES}

1. CBS, Veranderingen in de woningvoorraad, 2008, Centraal Bureau voor de Statistiek, online database, URL: http://statline.cbs.nl/StatWeb/publication/?VW=T\&DM=SLNL\& $\mathrm{PA}=37263 \& \mathrm{D} 1=0,2-3,10,13-15 \& \mathrm{D} 2=0,5-16 \& \mathrm{D} 3=4,9,14,19,24,29,34,39,44,49,54,59,64 \&$ $\mathrm{HD}=080617-1313 \& \mathrm{STB}=\mathrm{T}$.

2. SenterNovem, Strategisch Kader $\mathrm{CO}_{2}$-reductie in de Gebouwde Omgeving 2004, Utrecht, 44, 134.

3. Ministerie van VROM, Evaluatienota Klimaatbeleid 2005; Onderweg naar Kyoto; Een evaluatie van het Nederlandse klimaatbeleid gericht op realisering van de verplichtingen in het Protocol van Kyoto's, Gravenhage, 2005, 8.

4. Ministerie van VROM, Cijfers over Wonen 2004; Feiten over mensen, wensen, wonen, Directoraat-Generaal Wonen's,' Gravenhage, 2004, 109, 118.

5. Bouwend Nederland, De bouw in cijfers 2000-2004; uitgave 2005, Gouda, June 2005, 62. 
6. Meijaard, J., Innovation policy and the construction sector in the Netherlands, in: Innovation in construction; an international review of public policies, Manseau, A. and Seaden, G., 2001, Spon Press: London, 299-312.

7. SenterNovem, Cijfers en tabellen 2006, 2006, Utrecht, 18.

8. Koffijberg, J.J., Getijden van beleid: omslagpunten in de volkshuisvesting; Over de rol van hierarchie en netwerken bij grote veranderingen, thesis, Ph.D., OTB. 2005, Technische Universiteit Delft: Delft, 69-71.

9. SenterNovem, Voorbeeldwoningen bestaande bouw 2007, SenterNovem, Utrecht, 2007, 3-67.

10. Stuurgroep Nationaal Isolatie Programma, Evaluatie 10 jaar Nationaal Isolatie Programma, Ministerie van VROM, 1988, 15.

11. ECN, Energie Verslag Nederland 2000, 2001, Energieonderzoek Centrum Nederland: Petten, Amsterdam, 7-8.

12. ECN, Energie Verslag Nederland 2004, 2005, ECN Beleidsstudies: Petten /Amsterdam. 19-20.

13. Switzer, S., Public Benefits Charges to Fund Resource Acquisition Programs: An Orwellian Tale, The Electricity Journal, 2002, 15(8), 48. 